\title{
A Carbon-Support-Free Titanium Oxynitride Catalyst for Proton Exchange Membrane Fuel Cell Cathodes
}

\author{
Mitsuharu Chisaka, ${ }^{a, b} *$ Yuta Ando, ${ }^{a}$ Yusuke Yamamoto, ${ }^{a}$ and Noriaki Itagaki ${ }^{a}$ \\ ${ }^{a}$ Department of Electronics and Information Technology, Hirosaki University, \\ 3 Bunkyo-cho, Hirosaki, Aomori 036-8561, Japan \\ ${ }^{\mathrm{b}}$ Present address : Department of Sustainable Energy, Hirosaki University, 3 Bunkyo-cho, Hirosaki, \\ Aomori 036-8561, Japan \\ *Author to whom correspondence should be addressed. \\ Mitsuharu Chisaka \\ Phone/Fax: +81 172393559 E-mail: chisaka@ hirosaki-u.ac.jp.




\begin{abstract}
Cathode catalysts without platinum group metals (PGMs) or carbon supports can reduce the price of polymer electrolyte fuel cells in automobiles, making them commercially competitive. In this paper, an inexpensive and PGM-free catalyst-amorphous nitrogen-doped $\mathrm{TiO}_{2}$-shell on TiN-core- was synthesized without carbon support. While existing PGM-free all-oxide catalysts without carbon support have shown moderate current densities (at the order of $\mu \mathrm{A} / \mathrm{cm}^{2}$ ), the current density of this new catalyst is three orders of magnitude higher. Replacing commercial carbon support by hydrothermally synthesized $\mathrm{Ti}_{4} \mathrm{O}_{7}$ significantly enhanced the activity to be close to that of carbon-supported platinum. Although its conductivity and surface area were not sufficient for an accurate evaluation of its activity, these new results demonstrate the possibility of high-performance non-PGM catalysts without carbon supports.
\end{abstract}




\section{Introduction}

Due to concerns of pollution and global warming, there is an urgent need to reduce the emission from automobiles on the global scale, and some countries have implemented nearly zero emission limits. While the lithium-ion battery and other energy storage/conversion devices can eliminate emission in smaller vehicles, the proton exchange membrane fuel cell (PEFC) is more suitable for "high-load vehicles" such as trucks, buses and vehicles that operate over long distances ( $>500$ kilometres $).{ }^{1}$ The PEFC-powered vehicles have been commercialized recently, yet their prices remain high due to the scarce and expensive platinum group metals (PGMs) in the catalysts, as well as the need to protect carbon-black supports from corrosion. ${ }^{2,3}$ In PEFC, the PGM loading required for oxygen reduction reaction (ORR) at the cathode is an order of magnitude higher than that for hydrogen oxidation reaction at the anode. At potentials above $0.207 \mathrm{~V}$ versus the standard hydrogen electrode, the carbon support corrodes. The corrosion rate is especially high during the startup/shutdown of the cell, due to the socalled reverse-current decay mechanism which increases the potential up to $\sim 1.5 \mathrm{~V} .^{4}$ Therefore, nonPGM cathode catalysts ${ }^{5-17}$ and/or PGM catalysts on carbon-free supports ${ }^{18-25}$ have been extensively developed to reduce the cost of PEFC.

Most known non-PGM catalysts utilize graphitic carbon materials as conductive supports and/or the catalyst itself. $^{7-14,16,17}$ Exceptions include sputtered thin-films, ${ }^{5}$ plates, ${ }^{6}$ and micron-sized powders ${ }^{15}$ of group IV/V metal oxides. These metal oxide catalysts are stable against leaching in acidic media. However, their poor conductivity leads to very moderate current density, with the geometric current density on the order of $\mu \mathrm{A} / \mathrm{cm}^{2}$ in the practical potential range. ${ }^{5,6,15}$ To increase the active surface area and the current density, conductive agents have been utilized to connect the oxide nanoparticles to the carbon supports. ${ }^{14,16}$

Oxides, ${ }^{18-22}$ nitrides $^{23,24}$, borides $^{25}$, and other carbon-free compounds have been used to support PGM catalysts. Some platinum catalysts on conductive oxide supports have shown better ORR activity than conventional carbon-supported platinum $(\mathrm{Pt}-\mathrm{C})$ or platinum-cobalt $(\mathrm{PtCo}-\mathrm{C})$ catalysts. $^{21} \mathrm{The}^{2}$ 
conductive PGMs can show ORR activity when supported on non-conductive oxides, such as dopantfree $\mathrm{TiO}_{2} \cdot{ }^{19,21}$ On the other hand, all-oxide non-PGM catalysts on oxide supports remain a challenge due to the poor conductivity of the oxides.

Here we developed a new PGM-free oxynitride catalyst without carbon support. The moderate ORR activity of a previously developed carbon-supported titanium oxynitride $\left(\mathrm{TiO}_{x} \mathrm{~N}_{y}-\mathrm{C}\right)^{17}$ was significantly improved by replacing commercial carbon black support by hydrothermally synthesized $\mathrm{Ti}_{4} \mathrm{O}_{7}$ fibers. In acidic media, this catalyst achieved the highest activity among the ever reported carbon-support-free oxide catalysts and a limiting current density similar to $\mathrm{Pt}-\mathrm{C}$. This new record demonstrated the potential of all-oxide catalysts in PEFC cathodes.

\section{Experimental}

2.1 Synthesis of $\mathrm{Ti}_{4} \mathrm{O}_{7}$ supports: $0.6 \mathrm{~g}$ of $\mathrm{TiO}_{2}$ powder (P25, Japan Aerosil Co., Shinjuku-ku, Tokyo, Japan) was hydrothermally treated at $423 \mathrm{~K}$ for $72 \mathrm{~h}$ in $10 \mathrm{M} \mathrm{NaOH}$ solution using a Teflonlined autoclave. The autoclave was set in an aluminium block placed on a hot stirrer to continuously stir the dispersion. After the hydrothermal treatment, the autoclave was allowed to cool and opened after stopping the stirring. The obtained powder was washed with $\mathrm{HNO}_{3}$ solution until $\mathrm{pH} \leq 1$, then washed with distilled water until the $\mathrm{pH}$ became neutral. The washed powder was dried in a convection oven at $380 \mathrm{~K}$ for at least overnight. The absence of trace sodium was verified by XPS (Supplementary material). The dried powder was placed in an alumina boat which was then set in a horizontal quartz tube furnace. The furnace was slowly evacuated and purged with $5 \% \mathrm{H}_{2}$ in Ar. The support samples were heated from room temperature to $1323 \mathrm{~K}$ at a rate of $10 \mathrm{~K} \mathrm{~min}^{-1}$, then the temperature was maintained for $6 \mathrm{~h}$, and the samples were cooled to room temperature. The flow rate of $\mathrm{H}_{2} / \mathrm{Ar}$ was 500 standard cubic centimetres per minute $\left(\mathrm{sccm}, 1 \mathrm{sccm}=1.67 \times 10^{-8} \mathrm{~m}^{3} \mathrm{~s}^{-1}\right)$ during the pyrolysis. 
2.2 Catalyst synthesis: The catalysts were synthesized by modifying the solution-phase combustion route ${ }^{17}$ to replace carbon black with $\mathrm{Ti}_{4} \mathrm{O}_{7}$, or even without any support. Their structure which is shown later in section 3 is $\mathrm{TiN}$-core covered with amorphous nitrogen-doped $\mathrm{TiO}_{2}$-shell and we call this as $\mathrm{TiO}_{x} \mathrm{~N}_{y}$ for the shake of simplicity. A given mass of $\mathrm{Ti}_{4} \mathrm{O}_{7}$ support was dispersed in distilled water in a polytetrafluoroethylene (PTFE) beaker by stirring at room temperature. The bottom of the beaker was coated with a PTFE-carbon composite on the outside to facilitate heating within via a hot stirrer. Next, titanium tetrafluoride powder $\left(\mathrm{TiF}_{4}\right.$, Sigma-Aldrich Co., St. Louis, Missouri, U.S.) and urea powder $\left(\left(\mathrm{NH}_{2}\right)_{2} \mathrm{CO}\right.$, Wako Chemical Industries Ltd., Osaka, Osaka, Japan) were added to the dispersion with continuous stirring to achieve a mass ratio of $\mathrm{Ti}_{4} \mathrm{O}_{7}$ : $\mathrm{TiF}_{4}$-derived $\mathrm{TiO}_{2}$ :urea $=R: 1: 100$, where $R$ ranged from 0-2. Unless otherwise noted, $R$ was fixed at 1 . Then, 35\% (w/w) hydrochloric acid solution ( $\mathrm{HCl}$, Kishida Chemical Co., Osaka, Osaka, Japan) was added to the resulting dispersion till $\mathrm{pH} \leq 1$, in order to hydrolyze $\mathrm{TiF}_{4}$ and generate titanium hydroxides. ${ }^{17}$ The PTFE beaker was placed on another stirrer pre-heated to $523 \mathrm{~K}$, stirred continuously until the water evaporated, and then dried in a convection oven at least overnight at $380 \mathrm{~K}$. Subsequently, each precursor powder was placed in an alumina boat and inserted into another horizontal quartz-tube furnace (different from that used for the synthesis of $\mathrm{Ti}_{4} \mathrm{O}_{7}$ ). The tube was slowly evacuated, purged with $\mathrm{N}_{2}$ gas, then the powder samples were heated from room temperature to various temperatures at a rate of $10 \mathrm{~K} \mathrm{~min}^{-1}$ and maintained for $2 \mathrm{~h}$. Then the samples were cooled to room temperature at an uncontrolled rate. The $\mathrm{N}_{2}$ flow rate was $100 \mathrm{sccm}$ during pyrolysis. After pyrolysis, the powders were ground in an agate mortar. Note that some solid by-products became attached to the inner wall of the quartz tube during pyrolysis. Such by-products can stop the gas flow if they block the narrow opening of the quartz tube, and thus can be dangerous. We used a long quartz tube with a length that was more than three times longer than the heating zone to allow sufficient space for the accumulated by-products inside the tube and avoid blockage. After pyrolysis and the ejection of the alumina boats, the by-products were easily removed by washing the tube with water. 
2.3 Characterization: The morphology of the $\mathrm{TiO}_{x} \mathrm{~N}_{y}$ catalysts was investigated using a field emission-scanning electron microscope (JSM-7000F, JEOL, Akishima, Tokyo, Japan) and transmission electron micrscope (JEM-2100, JEOL, Akishima, Tokyo, Japan). The electrical conductivity, $\sigma$, of $\mathrm{Ti}_{4} \mathrm{O}_{7}$ support and $\mathrm{TiO}_{2}$ precursor were measured by a four-probe method with compressed pellets using a powder resistivity measurement system (MCP-PD51, Mitsubishi Chemical Analytech Co., Chigasaki, Kanagawa, Japan). The bulk crystal structures of the catalysts were analyzed using an X-ray diffractometer (M18XHF, Mac Science Co., Hachioji, Tokyo, Japan) with $\mathrm{Cu}-\mathrm{K} \alpha$ radiation generated at $30 \mathrm{kV}$ and $50 \mathrm{~mA}$ (scan range $10-80^{\circ}$, step size $0.02^{\circ}$, and scan rate $2^{\circ} \mathrm{min}^{-1}$ ). The surface crystal structures were analyzed using a Raman spectrometer (LabRAM HR Evolution, Horiba Co., Kyoto, Kyoto, Japan) with a 532-nm (visible) or 325-nm (UV) laser. The chemical states of the catalysts were determined using X-ray photoelectron spectroscopy (Quantera SXM, ULVAC-PHI, Inc., Chigasaki, Kanagawa, Japan) with an Al-Ka X-ray source $(1486.6 \mathrm{eV})$. The peak shifts caused by surface charge were corrected using the binding energy of $\mathrm{C} 1 \mathrm{~s}$ at $284.8 \mathrm{eV}$.

2.4 ORR activity and selectivity measurements in a half-cell: RDE and RRDE voltammograms were obtained to evaluate the ORR activity and selectivity of the catalysts. The catalyst, $5 \% \mathrm{w} / \mathrm{w}$ Nafion ${ }^{\circledR}$ ionomer solution (510211, Sigma-Aldrich Co., St. Louis, Missouri, U.S.) and isopropyl alcohol were sonicated together for $1200 \mathrm{~s}$ and then further mixed using a planetary mixer (Mazerustar KK250S, Kurabo Co., Osaka, Osaka, Japan) for 180 s to obtain a homogeneous catalyst ink. The mass fraction of Nafion in the catalyst layer, $\chi_{\mathrm{N}}$, was varied from $0-0.3$. The mass fraction of $\mathrm{TiO}_{x} \mathrm{~N}_{y}$ in the catalyst ink was adjusted to obtain a final $\mathrm{TiO}_{x} \mathrm{~N}_{y}$ catalyst loading of $m=2 \mathrm{mg} \mathrm{cm}^{-2}$ by dropping 6.4 $\mathrm{mm}^{3}$ aliquots of the catalyst ink onto a glassy carbon (GC) disk (4 mm diameter)-platinum ring ( $5 \mathrm{~mm}$ inner diameter and $7 \mathrm{~mm}$ outer diameter) electrode (012613, BAS Co., Japan). Prior to the treatment, the surface of the GC disk electrode was polished with 1.0 and $0.05 \mu \mathrm{m}$ alumina slurries, washed with water, and then dried at $320 \mathrm{~K}$ in air. Subsequently, the electrode was air-dried at $320 \mathrm{~K}$ for at least 600 s. It is noted that the present catalysts require a large $m$ value to form a uniform coating on the GC surface, owing to the high density as they are free of carbon supports. When $\chi_{\mathrm{N}}=0,1.0 \mathrm{~mm}^{3}$ of $0.5 \%$ 
Nafion solution (prepared by diluting 5\% w/w Nafion solution with ethanol) was dropped onto the surface of the catalyst-coated GC to stabilize the catalyst particles, followed by air-drying at $320 \mathrm{~K}$ for at least 600 s. A conventional three-electrode cell was used for the electrochemical measurements performed in $0.1 \mathrm{M} \mathrm{H}_{2} \mathrm{SO}_{4}$ at room temperature. The catalyst-coated $\mathrm{GC}$ disk-Pt ring electrode, a carbon rod (diameter: 5 mm, C-072591, Nilaco Co., Japan), and Ag/AgCl (3 M NaCl) electrode (RE1B, BAS Co., Sumida-ku, Tokyo, Japan) were used as the working, counter, and reference electrodes, respectively. The working electrode was set on a rotator (RRDE-3A, BAS Co., Japan). All working electrode potentials were referenced to the reversible hydrogen electrode (RHE). After sequentially bubbling with $\mathrm{O}_{2}$ and $\mathrm{N}_{2}$ for $1800 \mathrm{~s}$, the RDE and RRDE voltammograms were recorded by applying a disk potential $(E)$ of $0.11-1.26 \mathrm{~V}$ at a scan rate of $5 \mathrm{mV} \mathrm{s}^{-1}$ and a rotation speed of $1500 \mathrm{rpm}$, using a potentiostat (Model 2323, BAS Co., Sumida-ku, Tokyo, Japan). The ring potential was kept constant at 1.26 V to obtain the RRDE voltammograms. The ORR was measured by $\left|j_{\mathrm{O}}-j_{\mathrm{N}}\right|$, the difference between the current per unit geometrical area of the GC disk electrode obtained in $\mathrm{N}_{2}\left(j_{\mathrm{N}}=I_{\mathrm{N}} S^{-1}\right)$ and in $\mathrm{O}_{2}\left(j_{\mathrm{O}}=\right.$ $I_{\mathrm{O}} S^{-1}$ ). The $n$ values were calculated by analysing the RRDE voltammograms according to the following equation:

$$
n=-4 I_{\mathrm{d}} /\left(-I_{\mathrm{d}}+I_{\mathrm{r}} / N\right)
$$

where $I_{\mathrm{d}}$ and $I_{\mathrm{r}}$ denote the disk and ring currents after the background correction described above, respectively; and $N$ is the collection efficiency (0.424) provided by the manufacturer (BAS Co.). As a reference, Pt-C catalyst (36.7\% w/w platinum on Ketjen Black, TEC10E40E, Tanaka Kikinzoku Kogyo K.K, Chiyoda-ku, Tokyo, Japan) was used under identical conditions.

2.5 Single cell tests : Catalyst inks for the cathode catalyst layers were prepared from $\mathrm{TiO}_{x} \mathrm{~N}_{y}$ catalyst $(R=2, T=1173 \mathrm{~K})$, Ketjen black, $5 \% \mathrm{w} / \mathrm{w}$ Nafion ${ }^{\circledR}$ ionomer solution, water, and n-propanol at a mass ratio for $\mathrm{TiO}_{x} \mathrm{~N}_{y}$ : Nafion ${ }^{\circledR}$ ionomer : Ketjen black of 9:6:1. A planetary ball mill was used to grind dry catalyst and Ketjen black to provide conductivity. Catalyst inks for the anode catalyst layers were prepared from commercial Pt-C (TEC10E50E, Tanaka Kikinzoku Kogyo K.K.), 20\% Nafion ${ }^{\circledR}$ ionomer solution, water, and n-propanol. Each ink was prepared using a planetary ball mill with two 
kinds of zirconia ball to obtain a homogeneous catalyst ink. The cathode inks were painted on the gas diffusion-layer (Sigracet ${ }^{\circledR} 35$ BC, SGL Carbon Japan Co., Minato-ku, Tokyo, Japan) and dried in an oven at $343 \mathrm{~K}$. The catalyst-coated gas diffusion-layers were hot-pressed onto a side of a Nafion ${ }^{\circledR}$ membrane (NR-211, DuPont Co., Wilmington, DE, U.S.). The anode catalyst layers were prepared onto the opposite side of the membrane by decal transfer method. Following hot-pressing, the resulting membrane electrode assembly (MEA) was allowed to cool to room temperature. The $\mathrm{Pt}-\mathrm{C}$ loading at the anode was $0.65 \mathrm{mg} \mathrm{cm}^{-2}$, while the $\mathrm{TiO}_{x} \mathrm{~N}_{y}$ loading at the cathode was $4.7 \mathrm{mg} \mathrm{cm}^{-2}$.

The $V-j$ curves for a single cell with fabricated MEAs were measured galvanostatically using an electronic load (As-510-4, NF Co., Yokohama, Kanagawa, Japan). All measurements were performed at $353 \mathrm{~K}$. The reactant gases of $\mathrm{H}_{2}$ and $\mathrm{O}_{2}$ were humidified by passing them through separate water baths at $353 \mathrm{~K}$. The flow rate for both $\mathrm{H}_{2}$ and $\mathrm{O}_{2}$ was $500 \mathrm{sccm}$ whereas the back pressures (gage) were 0.2 $\mathrm{MPa}$ and 0.3 MPa for anode and cathode, respectively.

\section{Results and Discussion}

\subsection{Catalyst synthesis and characterization}

The carbon-free supports were synthesized by hydrothermally treating $\mathrm{TiO}_{2}$ powder in a $\mathrm{NaOH}$ solution, followed by pyrolysis in a reductive gas. Figure 1 shows the field emission-scanning electron microscopy (FE-SEM) image of the resulting $\mathrm{Ti}_{4} \mathrm{O}_{7}$ fibers and the inset shows the photograph. These fibers were bluish-black, similar to the previously reported $\mathrm{Ti}_{4} \mathrm{O}_{7}$ powders. ${ }^{18}$ The $\sigma$ was drastically increased by four orders of magnitude after the color change (Supplementary material). When the $\mathrm{TiO}_{2}$ precursor was directly pyrolyzed under the identical conditions, $\mathrm{Ti}_{6} \mathrm{O}_{11}$ powder was obtained indicating that hydrothermal treatment was necessary to synthesize $\mathrm{Ti}_{4} \mathrm{O}_{7}$ fiber.

(Figure 1) 
The morphology was drastically changed after they were mixed with $\mathrm{TiF}_{4}$ and urea in water, followed by pyrolysis in $\mathrm{N}_{2}$ gas, as shown in Figure 2. The fibers were replaced by interconnected particles $<10 \mathrm{~nm}$ in size. The high resolution transmission electron microscopy (TEM) image indicates that these particles did not crystallize well, and energy dispersive spectroscopy analyses revealed the presence of titanium atoms (Supplementary material). These results and results shown later in Figure 3 indicate that the nanoparticles in Figure 2 are amorphous $\mathrm{TiO}_{x} \mathrm{~N}_{y}$. The two sources of titanium in the nanoparticles, namely $\mathrm{TiF}_{4}$ and $\mathrm{Ti}_{4} \mathrm{O}_{7}$, cannot be distinguished from each other in the current study. However, the original fibers of $\mathrm{Ti}_{4} \mathrm{O}_{7}$ were completely converted to particles by pyrolysis with urea. Fu et al. reported that titanate nanotubes hydrothermally synthesized in $\mathrm{NaOH}$ solution became tabular $\mathrm{TiO}_{x} \mathrm{~N}_{y}$ nanoparticles after nitrogen-doping with $\mathrm{NH}_{4} \mathrm{Cl}$ by pyrolysis. ${ }^{26}$ In this study, nitrogen-doping has drastically changed the $\mathrm{TiO}_{x} \mathrm{~N}_{y}$ morphology in a similar way.

(Figure 2)

Figure 3a shows the X-ray diffraction (XRD) patterns of $\mathrm{TiO}_{x} \mathrm{~N}_{y}$ catalysts after pyrolysis with urea at temperatures $T=1073-1323 \mathrm{~K}$ under flowing $\mathrm{N}_{2}$ gas. This step eliminated the $\mathrm{Ti}_{4} \mathrm{O}_{7}$ phase of the supports and produced a mixture of rutile- $\mathrm{TiO}_{2}$ and $\mathrm{TiN}$ phases. As $T$ was increased, the rutile peaks broadened and became weaker, whereas the TiN peaks sharpened, indicating that urea or its by-products reacted with $\mathrm{TiO}_{2}$ at higher temperatures. The reaction reduced the content and crystallinity of rutile$\mathrm{TiO}_{2}$ while increased the TiN content. The surface crystal structure was investigated using visible Raman spectroscopy excited at $532 \mathrm{~nm}$. As shown in Figure 3b, when $T \leq 1223 \mathrm{~K}$ the Raman spectra are assigned to pure rutile- $\mathrm{TiO}_{2}$ whose typical shifts are $\sim 142, \sim 250, \sim 446$, and $608 \mathrm{~cm}^{-1}$ for the $B_{1 \mathrm{~g}}$ mode, second-order scattering or dynamic disorder of the $\mathrm{TiO}_{6}$ octahedra, the $E_{\mathrm{g}}$ and $A_{1 \mathrm{~g}}$ modes, 
respectively. ${ }^{27,28}$ These peaks broadened with increasing $T$, suggesting the amorphization and randomizing effects of oxygen defects in the crystal. ${ }^{28}$ Two other broad peaks appeared at $\sim 200$ and $\sim 530 \mathrm{~cm}^{-1}$ when $T \geq 1273 \mathrm{~K}$. They are different from the typical shifts from TiN and anatase $\mathrm{TiO}_{2}{ }^{27-29}$ but similar to those of amorphous $\mathrm{TiO}_{2}$ prepared by anodic oxidation of titanium foils. ${ }^{30}$ None of the catalysts showed Raman active peaks of TiN, whereas their corresponding XRD patterns (Figure 3a) contained TiN peaks. Such a disagreement, which has often been reported, ${ }^{17,31}$ is due to the different detection limits of these two characterization techniques. As X-ray penetrates deeper into the bulk $\mathrm{TiO}_{x} \mathrm{~N}_{y}$ than the light used in the Raman spectrometer, these results suggest that the TiN surface was oxidized to form rutile/amorphous $\mathrm{TiO}_{2}$.

The chemical states of the $\mathrm{TiO}_{x} \mathrm{~N}_{y}$ catalysts were investigated using X-ray photoelectron spectroscopy (XPS). The Ti $2 p$ and $N$ 1s spectra are shown in Figure $3 \mathrm{c}$, while the $\mathrm{O}$ 1s spectra were not shown due to contribution from hydrocarbon contamination in the spectrometer. The Ti $2 p$ level is wellknown to be split into Ti $2 p_{3 / 2}$ and $2 p_{1 / 2}$ sublevels by spin-orbit coupling, displaying a doublet in the spectra. Three pairs of such doublets are seen in all four spectra in Figure $3 \mathrm{c}(\mathrm{left})$, indicating that each $\mathrm{TiO}_{x} \mathrm{~N}_{y}$ catalyst contained at least three different chemical states of Ti. In each spectrum, the two binding energies of the strongest doublet $\left(458.1-458.8 \mathrm{eV}\right.$ for Ti $2 \mathrm{p}_{3 / 2}$, and $464.0-464.4 \mathrm{eV}$ for Ti $2 \mathrm{p}_{1 / 2}$ ) are slightly lower than the typical values of $\mathrm{Ti}^{4+}$ in $\mathrm{TiO}_{2}$ crystal. ${ }^{32-34}$ Saha et al. reported that the $\mathrm{Ti} 2 \mathrm{p}_{3 / 2}$ peak binding energy of crystalline and amorphous $\mathrm{TiO}_{2}$ were 459.2 and $458.6 \mathrm{eV}$, respectively. ${ }^{32}$ Therefore, the amorphous surface of the $\mathrm{TiO}_{x} \mathrm{~N}_{y}$ catalysts could be the reason for shifted major peak binding energies shown in Figure 3c. In all Ti $2 \mathrm{p}$ spectra, $\sim 60 \%$ of the peak area is occupied by the major doublet originating from $\mathrm{Ti}^{4+}$. This indicates that the surface is oxidized, which is well in agreement with the trend observed in Raman spectra (Figure 3b). The catalysts showed two shoulder peaks in the Ti $2 \mathrm{p}_{3 / 2}$ region. The larger one at $456.4-456.9 \mathrm{eV}$ is assigned to one or more of the bonding states in $\mathrm{TiO}_{x} \mathrm{~N}_{y}{ }^{32-34}$ and the smaller one at $455.2-455.6 \mathrm{eV}$ is assigned to $\mathrm{N}-\mathrm{Ti}-\mathrm{N}$ bonding in $\mathrm{TiN}^{23,32}$ The larger shoulder has at least two possible origins, as nitrogen can affect the binding energy of titanium via two routes: replacing the oxygen atoms in the $\mathrm{TiO}_{2}$ lattice substitutionally, and bridging the 
oxygen and titanium atoms in the $\mathrm{TiO}_{2}$ lattice interstitially. In the $\mathrm{N}$ 1s spectra shown in Figure $3 \mathrm{c}$ (right), the four peaks at 395.9-396.2, 397.2-397.4, 398.9-399.1, and 400.4-401.0 eV are assigned to (1) N-Ti-N bonding in $\mathrm{TiN}^{32}$ (2) $\mathrm{N}-\mathrm{Ti}-\mathrm{N}$ bonding in the nitrogen-substituted $\mathrm{TiO}_{2}$ lattice, ${ }^{35,36}$ (3) $\mathrm{O}-$ Ti-N bonding in the nitrogen-substituted $\mathrm{TiO}_{2}$ lattice, ${ }^{33-36}$ and (4) $\mathrm{Ti}-\mathrm{O}-\mathrm{N}(-\mathrm{Ti})$ bonding in the $\mathrm{TiO}_{2}$ lattice containing interstitial nitrogen, ${ }^{34-36}$ respectively. When $T=1073 \mathrm{~K}$, (3) accounts for the largest fraction of N 1s spectrum in Figure 3c(i). When $T$ was increased to $1273 \mathrm{~K}$, the area fraction of (3) decreased whereas that of (2) increased as shown in Figure 3c(i)-(iii), indicating that the increased number of oxygen atoms in $\mathrm{TiO}_{2}$ were substituted by nitrogen in this temperature range. When $T$ was further increased to $1323 \mathrm{~K}$, the area fraction of (2) decreased while that of (1) became dominant, implying that some of the surface $\mathrm{TiO}_{2}$ was converted to $\mathrm{TiN}$. These observations agree well with the trend observed in the Ti $2 p$ spectra, in which the area fraction of the TiN-derived doublet at $\sim 455$ and $\sim 461 \mathrm{eV}$ was $0.10-0.11$ for $1073 \mathrm{~K} \leq T \leq 1273 \mathrm{~K}$ and 0.15 at $1323 \mathrm{~K}$.

(Figure 3)

\subsection{ORR activity in the half-cell and single cell}

Figure 4a shows the rotating disk electrode (RDE) voltammograms of the four $\mathrm{TiO}_{x} \mathrm{~N}_{y}$ catalysts. All voltammograms have been corrected for background, i.e., the geometric current density in $\mathrm{N}_{2}$ atmosphere $\left(j_{\mathrm{N}}\right)$ was subtracted from that in $\mathrm{O}_{2}\left(j_{\mathrm{O}}\right)$. Although these catalysts were synthesized without carbon support, their limiting current densities are as high as above $4 \mathrm{~mA} \mathrm{~cm}{ }^{-2}$. The best two catalysts at the optimal $T$ range of $1223-1273 \mathrm{~K}$ exhibited $1 \mathrm{~mA} \mathrm{~cm}{ }^{-2}$ at $E=0.7 \mathrm{~V}$. The other known carbonsupport-free oxide catalysts showed three orders of magnitude lower current density at the $E$ with different $m$. The $0.7 \mathrm{~V}$ was selected to compare the current density of different carbon-support-free oxide/oxynitride catalysts because it is practical to be used in vehicles ${ }^{37}$ and the ORR is assumed to 

$\mathrm{TiO}_{x}$ plates showed ca. $0.1 \mu \mathrm{A} \mathrm{cm}^{-2}$ ( $m$ was $40 \mathrm{mg} \mathrm{cm}^{-2}$ assuming that the density of $\mathrm{TiO}_{x}$ plate was $4 \mathrm{~g}$ $\left.\mathrm{cm}^{-3}\right)^{6}$ and binary oxide of titanium and niobium showed $0.26 \mu \mathrm{A} \mathrm{cm}{ }^{-2}\left(m\right.$ was ca. $\left.0.5 \mathrm{mg} \mathrm{cm}^{-2}\right){ }^{15}$ When assuming that the current density of these catalysts is proportional to $m$, that of $\mathrm{TiO}_{x}$ plates and the binary oxides are 0.005 and $1 \mu \mathrm{A} \mathrm{cm}^{-2}$, respectively when the $m$ was identical to that used in Figure 4 of this work, $2 \mathrm{mg} \mathrm{cm}{ }^{-2}$. These catalysts and the present $\mathrm{TiO}_{x} \mathrm{~N}_{y}$ catalysts were evaluated without carbon black additive in the half-cell. Even with the help of carbon black additive, tantalum oxide catalysts showed $0.1 \mathrm{~mA} \mathrm{~cm}{ }^{-2}$ at $E=0.7 \mathrm{~V}$ ( $m$ was ca. $9 \mathrm{mg} \mathrm{cm}^{-2}$ ) in the half-cell, ${ }^{38}$ which equals to $0.02 \mathrm{~mA} \mathrm{~cm}^{-2}$ at $m=2 \mathrm{mg} \mathrm{cm}^{-2}$ with the assumption. The assumption is rough but these results indicate that the present $\mathrm{TiO}_{x} \mathrm{~N}_{y}$ catalyst series contains the highest number of active sites among the known carbon-support-free oxide catalysts. The activity increased as $T$ was increased to $1223-1273 \mathrm{~K}$ but decreased at the higher temperature. The $j_{\mathrm{O}}-j_{\mathrm{N}}$ should be affected by the surface area of these $\mathrm{TiO}_{x} \mathrm{~N}_{y}$ catalysts and thus normalized current, $\left(I_{\mathrm{O}}-I_{\mathrm{N}}\right) I_{\mathrm{N}}{ }^{-1}$ was used to compensate the effect as $I_{\mathrm{N}}$ is proportional to the surface area. ${ }^{39,40}$ Their Tafel plots are shown in the inset. The trend observed from the RDE voltammograms did not change, indicating that the highest activity observed at the optimal $T$ range of $1223-1273 \mathrm{~K}$ was not originated from the surface area, but the intrinsic activity. The highest limiting current density of $1073 \mathrm{~K}$ sample, approximately $5 \mathrm{~mA} \mathrm{~cm}{ }^{-2}$ was not originated from the intrinsic activity. At the low $E$ region, oxygen diffusion could restrict the ORR. In general, particles aggregate during the pyrolysis and the size of aggregates increases with increasing $T$. The results shown in Figure $4 \mathrm{a}$ suggest that $\mathrm{TiO}_{x} \mathrm{~N}_{y}$ catalysts did not severely aggregate to restrict the oxygen transport at the lowest $T$. The activity of this optimal catalyst (i.e., $T=1273 \mathrm{~K}$ ) is compared in Figure $4 \mathrm{~b}$ with those of two catalysts supported by carbon black, namely commercial $\mathrm{Pt}-\mathrm{C}$ and $\mathrm{TiO}_{x} \mathrm{~N}_{y}-\mathrm{C}$ synthesized using Vulcan XC-72 under optimized conditions ${ }^{17}$ with different $m$. Because the present $\mathrm{TiO}_{x} \mathrm{~N}_{y}$ catalysts are much denser than the carbon-supported catalysts, a high $m$ value of $2 \mathrm{mg} \mathrm{cm}^{-2}$ was necessary to form the former into visually uniform layers without "catalyst islands" on the glassy carbon disk electrode. This value is much larger than the minimum value for $\mathrm{TiO}_{x} \mathrm{~N}_{y}-\mathrm{C}$ in reference $17\left(0.28 \mathrm{mg} \mathrm{cm}^{-2}\right)$. Therefore, 
the $m$ values for all four $\mathrm{TiO}_{x} \mathrm{~N}_{y}$ catalysts were set at $2 \mathrm{mg} \mathrm{cm}^{-2}$ whereas the $m$ values for $\mathrm{Pt}-\mathrm{C}$ and $\mathrm{TiO}_{x} \mathrm{~N}_{y}-\mathrm{C}$ were both set at $1 \mathrm{mg} \mathrm{cm}{ }^{-2}$, larger than the minimum required value. Replacement of carbon support by $\mathrm{Ti}_{4} \mathrm{O}_{7}$ significantly enhanced the activity to be close to that of $\mathrm{Pt}-\mathrm{C}$. Tafel slope, which is independent on $m$ in general, ${ }^{41}$ was calculated using kinetic current density. ${ }^{17}$ It was $85 \mathrm{mV} \mathrm{dec}{ }^{-1}$ for the $\mathrm{TiO}_{x} \mathrm{~N}_{y}$ and $63 \mathrm{mV} \mathrm{dec}{ }^{-1}$ for $\mathrm{Pt}-\mathrm{C}$, suggesting that the rate determining step of the former is complex and could involve both the charge transfer and intermediate transport. ${ }^{8}$ Although the present $\mathrm{TiO}_{x} \mathrm{~N}_{y}$ catalyst series contains the highest number of active sites which electrons could access, the conductivity of the $\mathrm{TiO}_{x} \mathrm{~N}_{y}$ catalyst and/or the porosity of the catalyst layer should be further increased, because the activity is reduced by increasing the Nafion content in the catalyst layers as shown in Figure 5.

(Figure 4)

(Figure 5)

In the two $\mathrm{TiO}_{x} \mathrm{~N}_{y}$ catalysts with the highest activity $(T=1223$ and $1273 \mathrm{~K})$, the surface crystal structure was converted from rutile to amorphous with substitutionally doped nitrogen atoms and defects according to Figures $3 \mathrm{~b}$ and $3 \mathrm{c}$. Rutile $\mathrm{TiO}_{2}$ is known to be more ready to incorporate oxygen defects owing to the lower number of shared edges in its $\mathrm{TiO}_{6}$ octahedra than anatase. ${ }^{31}$ Defects on the rutile $\mathrm{TiO}_{2}\left(\begin{array}{lll}1 & 1 & 0\end{array}\right)$ plane are favourable for the dissociative adsorption of oxygen molecules, ${ }^{42-44}$ which is the first step of ORR. Our previous studies revealed that the ORR activity of nitrogen-doped rutile $\mathrm{TiO}_{2}$ is higher than that of the anatase counterpart ${ }^{45,46}$ and the activity increased with increasing the number of defects. ${ }^{17}$ These observations support the hypothesis that the defects can serve as active sites in oxide catalysts in both acidic ${ }^{38}$ and alkaline media. ${ }^{47}$ In this study, the catalyst with the highest activity $(T=$ $1273 \mathrm{~K})$ was amorphous with a broad visible Raman spectrum. This is different from the sample prepared at $1223 \mathrm{~K}$ (Figure 3b), although they showed similar levels of activity according to Figure 4a. 
The crystal structures of their surfaces were examined by ultraviolet (UV) Raman spectroscopy excited at $325 \mathrm{~nm}$, as it is more surface-sensitive than visible Raman spectroscopy excited at $532 \mathrm{~nm} .{ }^{48}$ In spite of their different visible Raman spectra (Figure 3b (ii)-(iii)), these two catalysts showed almost the same UV Raman spectra without sharp peaks as shown in Figure 6, indicating that their top surfaces were both amorphous. The more disordered amorphous $\mathrm{TiO}_{2}$ is known to possess more defects for oxygen molecule adsorption than crystalline $\mathrm{TiO}_{2}$. For example, Lu et al. reported that amorphous $\mathrm{TiO}_{2}$ nanotube-arrays exhibited much higher sensitivity for oxygen molecules at $373 \mathrm{~K}$ than anatase. ${ }^{49}$ Therefore, not only rutile but also amorphous $\mathrm{TiO}_{2}$ could contain highly active sites for ORR, as proposed here for the first time for amorphous $\mathrm{TiO}_{2}$ with substitutionally doped nitrogen atoms. The emergence of such amorphous phase revealed by UV Raman spectra shown in Figure 6 as well as increase in the active site density from $\mathrm{TiO}_{x} \mathrm{~N}_{y}$ by removing the carbon-supports could be the reasons for the higher activity of $\mathrm{TiO}_{x} \mathrm{~N}_{y}$ than $\mathrm{TiO}_{x} \mathrm{~N}_{\mathrm{y}}-\mathrm{C}$, as displayed in Figure $4 \mathrm{~b}$. When $T$ was increased to 1323 $\mathrm{K}$, the activity declined sharply (Figure $4 \mathrm{a}$ ), due to the increased content of inactive surface TiN, ${ }^{17}$ whose content changed from $0.10-0.11$ to 0.15 as discussed in the context of the Ti $2 \mathrm{p}$ spectra in Figure 3c.

\section{(Figure 6)}

The effect of the mass ratio of $\mathrm{Ti}_{4} \mathrm{O}_{7}$ to $\mathrm{TiF}_{4}$-derived $\mathrm{TiO}_{2}(R)$ on the activity was systematically investigated after optimizing the pyrolysis condition for each $R$ value, and the results are shown in Figure 7. The activity increased as $R$ was increased from 0 to 1 , but it remained almost the same (with a slight increase in the limiting current density) when $R$ further increased to 2 , indicating that the $\operatorname{Ti}_{4} \mathrm{O}_{7}$ support was necessary to maximize the catalyst activity. 
Figure 5 suggests that the conductivity of $\mathrm{TiO}_{x} \mathrm{~N}_{y}$ catalysts was too low for evaluating their activity with added Nafion in the catalyst layer. It is possible to evaluate the activity without Nafion in a half-cell, employing $0.1 \mathrm{M} \mathrm{H}_{2} \mathrm{SO}_{4}$ solution with abundant protons. However, the Nafion-ionomer is necessary in PEFC cathode catalyst layers for binding the catalyst particles and providing proton conductivity. Therefore, carbon additive was employed only in the cathode catalyst layers in order to use Nafionionomer in single-cell tests. In all half-cell tests, catalyst layers were formed without carbon additive. The MEAs were fabricated using $\operatorname{TiO}_{x} \mathrm{~N}_{y}(R=2)$ at the cathode and $\mathrm{Pt}-\mathrm{C}$ at the anode. The voltage versus current density $(V-j)$ curve is shown in Figure 8 . The $\mathrm{TiO}_{x} \mathrm{~N}_{y}$ acted as the cathode catalyst in the single cell with $0.92 \mathrm{~V}$ of an open circuit voltage. It is well known that when using Pt-C catalyst, parameters such as the mass fraction of Nafion in the catalyst layers ${ }^{50,51}$ and the solvent for preparing the catalyst "ink" 52,53 affect the structure of the catalyst layer, its proton/oxygen transport properties and the resulting single cell performance. These parameters should also be optimized for the $\mathrm{TiO}_{x} \mathrm{~N}_{y}$ catalysts.

(Figure 8)

Without carbon support, the present $\mathrm{TiO}_{x} \mathrm{~N}_{y}$ catalysts clearly demonstrated ORR activity for the first time. However, trace carbon from the urea precursor could not be excluded as it contains one carbon atom per molecule. We used $\mathrm{ZrF}_{4}$ instead of $\mathrm{TiF}_{4}$ to clarify the activity contributed by such trace carbon on the top surface, as confirmed by the weak G-band peak in UV Raman spectra shown in the right part of Figure 6. As all the synthetic and characterization conditions were identical, the activity due to trace carbon would be similar between $\mathrm{ZrF}_{4}$ and $\mathrm{TiF}_{4}$. However, the black-colored $\mathrm{TiO}_{x} \mathrm{~N}_{y}$ catalyst showed superior activity compared with the white-colored $\mathrm{ZrO}_{x} \mathrm{~N}_{y}$ as shown in Figure 9, indicating that the activity of the $\mathrm{TiO}_{x} \mathrm{~N}_{y}$ catalyst series was determined by oxynitride, not by carbon traces. Because 
titanium oxide is amenable to the incorporation of oxygen defects (which changed its colour to black) to increase the conductivity, support-free $\mathrm{TiO}_{x} \mathrm{~N}_{y}$ prepared at $T=1173 \mathrm{~K}$ showed activity. Under optimized pyrolysis conditions, the activity of the $\mathrm{TiO}_{x} \mathrm{~N}_{y}$ catalyst without $\mathrm{Ti}_{4} \mathrm{O}_{7}$ support was increased (Figure 7).

\section{(Figure 9)}

The activity of $\mathrm{TiO}_{x} \mathrm{~N}_{y}$ was the highest ever reported for carbon-support-free oxide catalysts and the limiting current density is similar to $\mathrm{Pt}-\mathrm{C}$. The catalysts were evaluated without Nafion-ionomer and carbon additive in the catalyst layer of the half-cell, and their activity was found to decrease with increasing Nafion content. Further, $2 \mathrm{mg} \mathrm{cm}^{-2}$ of high $m$ was needed in the half cell owing to the low surface area of $\mathrm{TiO}_{x} \mathrm{~N}_{y}$. To realize truly carbon-free cathode catalyst layers in MEAs used with Nafionionomer, the surface area and the conductivity of these catalysts should be increased. In this study, only one combination of $\mathrm{TiF}_{4}$, urea and water (as the sources of $\mathrm{Ti}, \mathrm{N}$, and solvent respectively) was investigated. The starting materials and their mixing conditions could be further optimized for smaller particle size and larger surface area. Retention of the conductive $\mathrm{Ti}_{4} \mathrm{O}_{7}$ phase in the supports, which disappeared during pyrolysis in $\mathrm{N}_{2}$, is the key to higher conductivity; and it can be achieved by replacing $\mathrm{N}_{2}$ with a reductive gas. These remaining issues suggest that the new $\mathrm{TiO}_{x} \mathrm{~N}_{y}$ catalysts still have plenty of room for improvement, even though they already increased over the results in our previous work. ${ }^{17}$

\section{Conclusions}

Carbon-support-free $\mathrm{TiO}_{x} \mathrm{~N}_{y}$ catalysts for PEFC cathodes were synthesized via a solution-phase combustion route using hydrothermally synthesized $\mathrm{Ti}_{4} \mathrm{O}_{7}$ supports. The fiber morphology and crystal 
structure of the support disappeared after nitrogen doping, and the fibers were replaced by interconnected amorphous $\mathrm{TiO}_{x} \mathrm{~N}_{y}$ particles. Compared with the previously reported $\mathrm{TiO}_{x} \mathrm{~N}_{y}-\mathrm{C}$, the $\mathrm{TiO}_{x} \mathrm{~N}_{y}$ catalyst increased the activity in the half-cell to be close to that of commercial $\mathrm{Pt}-\mathrm{C}$. This catalyst not only acted as a cathode catalyst in the single cell, but also displayed the highest reported activity among carbon-support-free oxide catalysts. This study opens up new routes to developing nonplatinum catalysts without carbon supports for PEFC in vehicles.

\section{References}

[1] U. Eberle, R. von Helmolt, R. Sustainable Transportation Based on Electric Vehicle Concepts: a Brief Overview. Energy Environ. Sci. 3 (2010) 689.

[2] T. Yoshida, K. Kojima, Toyota MIRAI Fuel Cell Vehicle and Progress Toward a Future Hydrogen Society. ECS Interface 24 (2015) 45.

[3] U. Eberle, B. Müller, R. von Helmolt, Fuel Cell Electric Vehicles and Hydrogen Infrastructure: Status 2012. Energy Environ. Sci. 5 (2012) 8780.

[4] C. A. Reiser, L. Bregoli, T. W. Patterson, J. S. Yi, J. D. Yang, M. L. Perry, T. D. A Jarvi, Reverse-Current Decay Mechanism for Fuel Cells. Electrochem. Solid-State Lett. 8 (2005) A273.

[5] Y. Liu, A. Ishihara, S. Mitsushima, N. Kamiya, K. Ota, Zirconium Oxide for PEFC Cathodes. Electrochem. Solid-State Lett. 8 (2005) A400.

[6] J. H. Kim, A. Ishihara, S. Mitsushima, N., Kamiya, K. Ota, Catalytic Activity of Titanium Oxide for Oxygen Reduction Reaction as a Non-Platinum Catalyst for PEFC. Electrochim. Acta 52 (2007) 2492.

[7] M. Lefevre, E. Proietti, F. Jaouen, J. P. Dodelet, Iron-Based Catalysts with Improved Oxygen Reduction Activity in Polymer Electrolyte Fuel Cells. Science 324 (2009) 71.

[8] G. Wu, K. L. More, C. M. Johnston, P. Zelenay, High-Performance Electrocatalysts for Oxygen Reduction Derived from Polyaniline, Iron, and Cobalt. Science 332 (2011) 443. 
[9] E. Proietti, F. Jaouen, M. Lefevre, N. Larouche, J. Tian, J. Herranz, J. P. Dodelet, Iron-Based Cathode Catalyst with Enhanced Power Density in Polymer Electrolyte Membrane Fuel Cells. Nature Commun. 2 (2011) 416.

[10] Y. Li, W. Zhou, H. Wang, L. Xie, Y. Liang, F. Wei, J. C. Idrobo, S. J. Pennycook, H. Dai, An Oxygen Reduction Electrocatalyst Based on Carbon Nanotube-Graphene Complexes. Nature Nanotechnol. 7 (2012) 394.

[11] W. Wei, H. Liang, K. Parvez, X. Zhuang, X. Feng, K. Müllen. Nitrogen-Doped Carbon Nanosheets with Size-Defined Mesopores as Highly Efficient Metal-Free Catalyst for the Oxygen Reduction Reaction. Angew. Chem. 126 (2014) 1596.

[12] J. Shui, M. Wang, F. Du, L. Dai, N-doped Carbon Nanomaterials are Durable Catalysts for Oxygen Reduction Reaction in Acidic Fuel Cells. Sci. Adv. 1 (2015) e1400129.

[13] Y. C. Wang, Y. J. Lai, L. Song, Z. Y. Zhou, J. G. Liu, Q. Wang, X. D. Yang, C. Chen, W. Shi, Y. P. Zheng, M. Rauf, S. G. Sun, S-Doping of an Fe/N/C ORR Catalyst for Polymer Electrolyte Membrane Fuel Cells with High Power Density. Angew. Chem. Int. Ed. 54 (2015) 9907.

[14] A. Ishihara, M., Chisaka, Y. Ohgi, K. Matsuzawa, S. Mitsushima, K. Ota, Synthesis of Nano$\mathrm{TaO}_{\mathrm{x}}$ Oxygen Reduction Reaction Catalysts on Multi-Walled Carbon Nanotubes Connected via a Decomposition of Oxy-tantalum Phthalocyanine, Phys. Chem. Chem. Phys. 17 (2015) 7643.

[15] A. Ishihara, M. Hamazaki, M. Arao, M. Matsumoto, H. Imai, Y. Kohno, K. Matsuzawa, S. Mitsushima, K. Ota, Titanium-Niobium Oxides Mixed with $\mathrm{Ti}_{4} \mathrm{O}_{7}$ as Precious-Metal-and CarbonFree Cathodes for Polymer Electrolyte Fuel Cells. J. Electrochem. Soc. 163 (2016) F603.

[16] M. Chisaka, N. Itagaki, Evaluation and Enhancement of the Oxygen Reduction Reaction Activity on Hafnium Oxide Nanoparticles Assisted by L(+)-lysine. Electrochim. Acta 201 (2016) 279.

[17] M. Chisaka, Y. Ando, N. Itagaki, Activity and Durability of the Oxygen Reduction Reaction in a Nitrogen-Doped Rutile-Shell on TiN-Core Nanocatalysts Synthesised via Solution-Phase Combustion. J. Mater. Chem. A 4 (2016) 2501.

[18] T. Ioroi, Z. Siroma, N. Fujiwara, S. Yamazaki, K. Yasuda, Sub-Stoichiometric Titanium Oxide- 
Supported Platinum Electrocatalyst for Polymer Electrolyte Fuel Cells. Electrochem. Commun. 7 (2005) 183.

[19] S. Y. Huang, P. Ganesan, S. Park, B. N. Popov, Development of a Titanium Dioxide-Supported Platinum Catalyst with Ultrahigh Stability for Polymer Electrolyte Membrane Fuel Cell Applications. J. Am. Chem. Soc. 131 (2009) 13808.

[20] A. Masao, S. Noda, F. Takasaki, K. Ito, K. Sasaki, Carbon-Free Pt Electrocatalysts Supported on $\mathrm{SnO}_{2}$ for Polymer Electrolyte Fuel Cells. Electrochem. Solid-State Lett. 12 (2009) B119.

[21] V. Thi, T. Ho, C. J. Pan, J. Rick, W. N. Su, B. J. Hwang, Nanostructured $\mathrm{Ti}_{0.7} \mathrm{Mo}_{0.3} \mathrm{O}_{2}$ Support Enhances Electron Transfer to Pt: High-Performance Catalyst for Oxygen Reduction Reaction. J. Am. Chem. Soc. 133 (2011) 11716.

[22] K. Kakinuma, Y. Chino, Y. Senoo, M. Uchida, T. Kamino, H. Uchida, S. Deki, M. Watanabe, Caracterization of $\mathrm{Pt}$ Catalysts on $\mathrm{Nb}$-doped and $\mathrm{Sb}$-doped $\mathrm{SnO}_{2-\delta}$ Support Materials with Aggregated Structure by Rotating Disk Electrode and Fuel Cell Measurements. Electrochim. Acta 110 (2013) 316

[23] B. Avasarala, T. Murray, W. Li, P. Haldar, Titanium Nitride Nanoparticles Based Electrocatalysts for Proton Exchange Membrane Fuel Cells. J. Mater. Chem. 19 (2009) 1803.

[24] K. Kakinuma, Y. Wakasugi, M. Uchida, T. Kamino, H. Uchida, S. Deki, M. Watanabe Preparation of Titanium Nitride-Supported Platinum Catalysts with Well Controlled Morphology and Their Properties Relevant to Polymer Electrolyte Fuel Cells. Electrochim. Acta 77 (2012) 279.

[25] S. Yin, S. Mu, M. Pan, Z. Fu, A Highly Stable $\mathrm{TiB}_{2}-$ Supported Pt Catalyst for Polymer Electrolyte Membrane Fuel Cells. J. Power Sources 196 (2011) 7931.

[26] J. Fu, Y. Tian, B. Chang, F. Xi, X. Dong, Facile Fabrication of N-doped $\mathrm{TiO}_{2}$ Nanocatalyst with Superior Performance under Visible Light Irradiation. J. Solid State Chem. 199 (2013) 280.

[27] S. P. S. Porto, P. A. Fleury, T. C. Damen, Raman Spectra of $\mathrm{TiO}_{2}, \mathrm{MgF}_{2}, \mathrm{ZnF}_{2}, \mathrm{FeF}_{2}$, and $\mathrm{MnF}_{2}$. Phys. Rev. 154 (1967) 522. 
[28] R. J. Betsch, H. L. Park W. B. White, Raman Spectra of Stoichometric and Defect Rutile. Mater. Res. Bull. 26 (1991) 613.

[29] Y. H. Cheng, B. K. Tay, S. P. Lau, H. Kupfer, F. Richter, Substrate Bias Dependence of Raman Spectra for TiN Films Deposited by Filtered Cathodic Vacuum Arc. J. Appl. Phys. 92 (2002) 1845.

[30] J. Zhao, X. Wang, R. Chen, L. Li, Fabrication of Titanium Oxide Nanotube Arrays by Anodic Oxidation. Solid State Commun. 134 (2005) 705.

[31] X. H. Wang, J. G. Li, H. Kamiyama, M. Katada, N. Ohashi, Y. Moriyoshi, T. Ishigaki, Pyrogenic Iron(III)-Doped $\mathrm{TiO}_{2}$ Nanopowders Synthesized in RF Thermal Plasma: Phase Formation, Defect Structure, Band Gap, and Magnetic Properties. J. Am. Chem. Soc. 127 (2005) 10982.

[32] N. C. Saha, H. G. Tompkins, Titanium Nitride Oxidation Chemistry: An X-ray Photoelectron Spectroscopy Study. J. Appl. Phys. 72 (1992) 3072.

[33] X. Chen, C. Burda, Photoelectron Spectroscopic Investigation of Nitrogen-Doped Titania Nanoparticles. J. Phys. Chem. B 108 (2004) 15446.

[34] Y. Cong, J. Zhang, F. Chen, M. Anpo, Synthesis and Characterization of Nitrogen-Doped $\mathrm{TiO}_{2}$ Nanophotocatalyst with High Visible Light Activity. J. Phys. Chem. C 111 (2007) 6976.

[35] J. Wang, W. Zhu, Y. Zhang, S. Liu, An Efficient Two-Step Technique for Nitrogen-Doped Titanium Dioxide Synthesizing: Visible-Light-Induced Photodecomposition of Methylene Blue. J. Phys. Chem. C 111 (2007) 1010.

[36] G. Yang, Z. Jiang, H. Shi, T. Xiao, Z. Yan, Preparation of Highly Visible-Light Active N-Doped $\mathrm{TiO}_{2}$ Photocatalyst. J. Mater. Chem. 20 (2010) 5301.

[37] A. Ohma, K. Shinohara, A. Iiyama, T. Yoshida, A. Daimaru, Membrane and Catalyst Performance Targets for Automotive Fuel Cells by FCCJ Membrane, Catalyst, MEA WG. ECS Trans. 41 (2011) 775 .

[38] A. Ishihara, M. Tamura, Y. Ohgi, M. Matsumoto, K. Matsuzawa, S., Mitsushima, H. Imai, K. Ota, Emergence of Oxygen Reduction Activity in Partially Oxidized Tantalum Carbonitrides: Roles of 
Deposited Carbon for Oxygen-Reduction-Reaction-Site Creation and Surface Electron Conduction. J. Phys. Chem. C 117 (2013) 18837.

[39] A. Ishihara, S. Doi, S. Mitsushima, K. Ota, Tantalum (oxy)Nitrides Prepared Using Reactive Sputtering for New Nonplatinum Cathodes of Polymer Electrolyte Fuel Cell. Electrochim. Acta $53(2008) 5442$.

[40] M. Chisaka, T. Iijima, A. Tomita, T. Yaguchi, Y. Sakurai, Oxygen Reduction Reaction Activity of Vulcan XC-72 Doped with Nitrogen Under $\mathrm{NH}_{3}$ Gas in Acid Media, J. Electrochem. Soc. 157 (2010) B1701.

[41] H. A. Gasteiger, J. E. Panels, S. G. Yan, Dependence of PEM Fuel Cell Performance on Catalyst Loading. J. Power Sources 127 (2004) 162.

[42] Y. Du, Z. Dohnálek, I. Lyubinetsky, Transient Mobility of Oxygen Adatoms upon $\mathrm{O}_{2}$ Dissociation on Reduced $\mathrm{TiO}_{2}$ (110), J. Phys. Chem. C 112 (2008) 2649.

[43] S. Wendt, P. T. Sprunger, E. Lira, G. K. H. Madsen, Z. Li, J. Hansen, J. Matthiesen, A. BlekingeRasmussen, E. L. Lægsgaard, B. Hammer, F. Besenbacher, The Role of Interstitial Sites in the Ti3d Defect State in the Band Gap of Titania, Science 320 (2008) 1755.

[44] Y. Du, N. A. Deskins, Z. Zhang, Z. Dohnalek, M. Dupuis, I. Lyubinetsky, Formation of O Adatom Pairs and Charge Transfer upon $\mathrm{O}_{2}$ Dissociation on Reduced $\mathrm{TiO}_{2}(110)$, Phys. Chem. Chem. Phys. 12 (2010) 6337.

[45] M. Chisaka, H. Muramoto, Reduced Graphene-Oxide-Supported Titanium Oxynitride as Oxygen Reduction Reaction Catalyst in Acid Media. ChemElectroChem, 1 (2014) 544.

[46] M. Chisaka, Y. Ando, H. Muramoto, Facile Combustion Synthesis of Carbon-Supported Titanium Oxynitride to Catalyse Oxygen Reduction Reaction in Acidic Media. Electrochim. Acta 183 (2015) 100.

[47] F. Cheng, T. Zhang, Y. Zhang, J. Du, X. Han, J. Chen, Enhancing Electrocatalytic Oxygen Reduction on $\mathrm{MnO}_{2}$ with Vacancies. Angew. Chem. Int. Ed. 52 (2013) 2474.

[48] J. Zhang, M. Li, Z. Feng, J. Chen, C. Li, UV Raman Spectroscopic Study on $\mathrm{TiO}_{2}$. I. Phase 
Transformation at the Surface and in the Bulk. J. Phys. Chem. B 110 (2006) 927.

[49] F. Lu, F. Li, G. Liu, Z. G. Chen, D. W. Wang, H. T. Fang, G.Q. Lu, Z. H. Jiang, H. M. Cheng, Amorphous $\mathrm{TiO}_{2}$ Nanotube Arrays for Low-Temperature Oxygen Sensors. Nanotechnol. 19 (2008) 405504.

[50] M. Uchida, Y. Fukuoka, Y. Sugawara, N. Eda, A. Ohta, Effects of Microstructure of Carbon Support in the Catalyst Layer on the Performance of Polymer-Electrolyte Fuel Cells. J. Electrochem. Soc. 143 (1996) 2245.

[51] P. Gode, F. Jaouen, G. Lindbergh, A. Lundblad, G. Sundholma, Influence of the composition on the structure and electrochemical characteristics of the PEFC cathode. Electrochim. Acta, 48 (2003) 4175.

[52] M. Uchida, Y. Aoyama, N. Eda, A. Ohta, New Preparation Method for Polymer-Electrolyte Fuel Cells. J. Electrochem. Soc., 142 (1995) 463.

[53] M. Chisaka, E. Matsuoka, H. Daiguji, Effect of Organic Solvents on the Pore Structure of Catalyst Layers in Polymer Electrolyte Membrane Fuel Cells. J. Electrochem. Soc. 157 (2010) B1218. 
Figure captions

Figure $1 \mathrm{FE}-\mathrm{SEM}$ image of the $\mathrm{Ti}_{4} \mathrm{O}_{7}$ fibers and their photograph (inset).

Figure 2 TEM image of $\mathrm{TiO}_{x} \mathrm{~N}_{y}$ catalyst prepared by pyrolysis at $1273 \mathrm{~K}$ for $2 \mathrm{~h}$ under flowing $\mathrm{N}_{2}$ gas. The mass ratio $(R)$ of $\mathrm{Ti}_{4} \mathrm{O}_{7}$ to $\mathrm{TiF}_{4}$-derived $\mathrm{TiO}_{2}$ was 1 .

Figure 3 (a) XRD patterns, (b) visible Raman spectra, and (c) XPS Ti 2p and N 1s spectra of $\mathrm{TiO}_{x} \mathrm{~N}_{y}$ catalysts after pyrolysis at four different temperatures: (i) $1073 \mathrm{~K}$, (ii) $1223 \mathrm{~K}$, (iii) $1273 \mathrm{~K}$ and (iv) 1323 $\mathrm{K}$, for a fixed duration of $2 \mathrm{~h}$ under flowing $\mathrm{N}_{2}$ gas and $R=1$.

Figure 4(a) RDE voltammograms of $\mathrm{TiO}_{x} \mathrm{~N}_{y}$ catalysts prepared by pyrolysis at four different temperatures: (i) $1073 \mathrm{~K}$, (ii) $1223 \mathrm{~K}$, (iii) $1273 \mathrm{~K}$, and (iv) $1323 \mathrm{~K}$ and (b) RDE voltammograms of (I) $\mathrm{TiO}_{x} \mathrm{~N}_{y}-\mathrm{C}$, (II) $\mathrm{TiO}_{x} \mathrm{~N}_{y}$, and (III) commercial Pt-C $(36.7 \% \mathrm{w} / \mathrm{w}$ platinum) catalysts. The inset in (a) shows the Tafel plots using normalized current. The optimized $T$ values used for (I) and (II) were 1173 $\mathrm{K}$ and $1273 \mathrm{~K}$, respectively. The scans were performed in $\mathrm{N}_{2}$ and $\mathrm{O}_{2}$ atmospheres, with the rotation speed of $1500 \mathrm{rpm}$ at a scan rate of $5 \mathrm{mV} \mathrm{s}^{-1}$ in $0.1 \mathrm{M} \mathrm{H}_{2} \mathrm{SO}_{4}$. The loading $(m)$ values for all carbonsupport-free $\mathrm{TiO}_{x} \mathrm{~N}_{y}$ samples were $2 \mathrm{mg} \mathrm{cm}^{-2}$, whereas those for carbon supported catalysts, $\mathrm{TiO}_{x} \mathrm{~N}_{y}-\mathrm{C}$ and $\mathrm{Pt}-\mathrm{C}$ was $1 \mathrm{mg} \mathrm{cm}^{-2}$. The loading of $\mathrm{Pt}$ particles with $\mathrm{Pt}-\mathrm{C}$ was $0.4 \mathrm{mg} \mathrm{cm}^{-2}$. The mass fraction of Nafion in the catalyst layers, $\chi_{\mathrm{N}}$, was 0 for $\mathrm{TiO}_{x} \mathrm{~N}_{y}$ and 0.3 for $\mathrm{TiO}_{x} \mathrm{~N}_{y}-\mathrm{C}$ and $\mathrm{Pt}-\mathrm{C}$. All the $\mathrm{TiO}_{x} \mathrm{~N}_{y}$ samples were prepared with $R=1$. No carbon was added to all catalyst layers.

Figure 5. RDE voltammograms of $\mathrm{TiO}_{x} \mathrm{~N}_{y}$ catalyst $(R=1)$ after pyrolysis at $1273 \mathrm{~K}$ for $2 \mathrm{~h}$ under flowing $\mathrm{N}_{2}$ gas, for four different mass fractions $\left(\chi_{\mathrm{N}}\right)$ of Nafion in the catalyst layers: (A) 0, (B) $0.05,(C)$ 
0.2 and (D) 0.3. The scans were performed under $\mathrm{N}_{2}$ and $\mathrm{O}_{2}$ atmospheres, with a rotation speed of 1500 rpm and a scan rate of $5 \mathrm{mV} \mathrm{s}^{-1}$ in $0.1 \mathrm{M} \mathrm{H}_{2} \mathrm{SO}_{4}$. The $m$ value was fixed at $2 \mathrm{mg} \mathrm{cm}^{-2}$. No carbon was added to the catalyst layers.

Figure 6. UV Raman spectra of $\mathrm{TiO}_{x} \mathrm{~N}_{y}$ catalyst $(R=1)$ after pyrolysis at $(\alpha) T=1223 \mathrm{~K}$ and $(\beta) T=$ $1273 \mathrm{~K}$ for $2 \mathrm{~h}$ under flowing $\mathrm{N}_{2}$ gas.

Figure 7. RDE voltammograms of $\mathrm{TiO}_{x} \mathrm{~N}_{y}$ catalysts with $R=0,1$ and 2 , which were pyrolyzed at the optimal $T$ values of 1123,1273 and $1173 \mathrm{~K}$, respectively. The scans were performed under $\mathrm{N}_{2}$ and $\mathrm{O}_{2}$ atmospheres, with a rotation speed of $1500 \mathrm{rpm}$ and a scan rate of $5 \mathrm{mV} \mathrm{s}^{-1}$ in $0.1 \mathrm{M} \mathrm{H}_{2} \mathrm{SO}_{4}$. The $\chi_{\mathrm{N}}$ and $m$ values for all samples were fixed at 0 and $2 \mathrm{mg} \mathrm{cm}^{-2}$, respectively. No carbon was added to the catalyst layers.

Figure 8. The $V-j$ curve of a single cell with MEA, using $\operatorname{TiO}_{x} \mathrm{~N}_{y}(R=2, T=1173 \mathrm{~K})$ at the cathode $(m$ $\left.=4.7 \mathrm{mg} \mathrm{cm}^{-2}\right)$ and $\mathrm{Pt}-\mathrm{C}$ at the anode $\left(0.65 \mathrm{mg} \mathrm{cm}^{-2}\right)$.

Figure 9. RDE voltammograms of $\mathrm{TiO}_{x} \mathrm{~N}_{y}$ and $\mathrm{ZrO}_{x} \mathrm{~N}_{y}$ catalysts synthesized without supports $(R=0)$ at $T=1173 \mathrm{~K}$. Their photographs are shown as insets. The scans were performed under $\mathrm{N}_{2}$ and $\mathrm{O}_{2}$ atmospheres, with a rotation speed of $1500 \mathrm{rpm}$ at a scan rate of $5 \mathrm{mV} \mathrm{s}^{-1}$ in $0.1 \mathrm{M} \mathrm{H}_{2} \mathrm{SO}_{4}$. The $m$ and $\chi_{\mathrm{N}}$ values were fixed at $1 \mathrm{mg} \mathrm{cm}^{-2}$ and 0.3 , respectively. No carbon was added to the catalyst layers. 


\section{Acknowledgments}

We thank Dr. Hiroyuki Morioka at Toppan Printing Co. Ltd and Mr. Yusei Tsushima at Hirosaki University for performing $V-J$ curve measurements and for help with obtaining FE-SEM/TEM images, respectively. This work was partially supported by a Grant-in-Aid for Scientific Research (C), 26420132, from the Ministry of Education, Culture, Sports, Science, and Technology (MEXT) in Japan; an Adaptable and Seamless Technology Transfer Program through Target-driven R\&D grant, AS262Z01049L, from the Japan Science and Technology Agency; a research grant from the Takahashi Industrial and Economic Research Foundation of Japan; a research grant from the Naoji Iwatani Foundation of Japan; a grant for chemical research from the Foundation for Japanese Chemical Research; a research grant from the Nippon Sheet Glass Foundation for Materials Science and Engineering and a research grant, KJ-2539, from the Kato Foundation for Promotion of Science. The XPS spectra were acquired with the support by Nanotechnology Platform, 12024046 of the MEXT in Japan. 


\section{Figure 1}

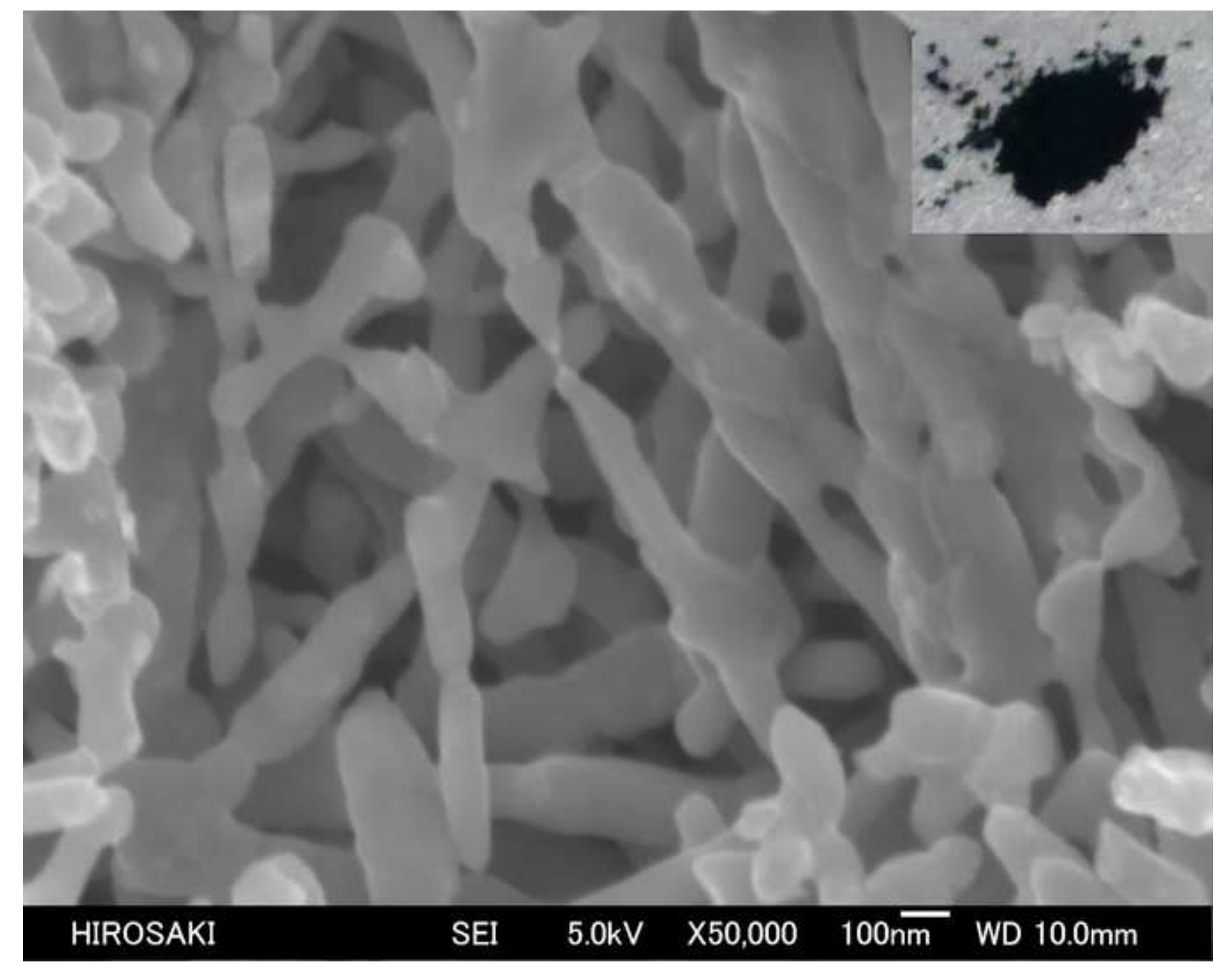




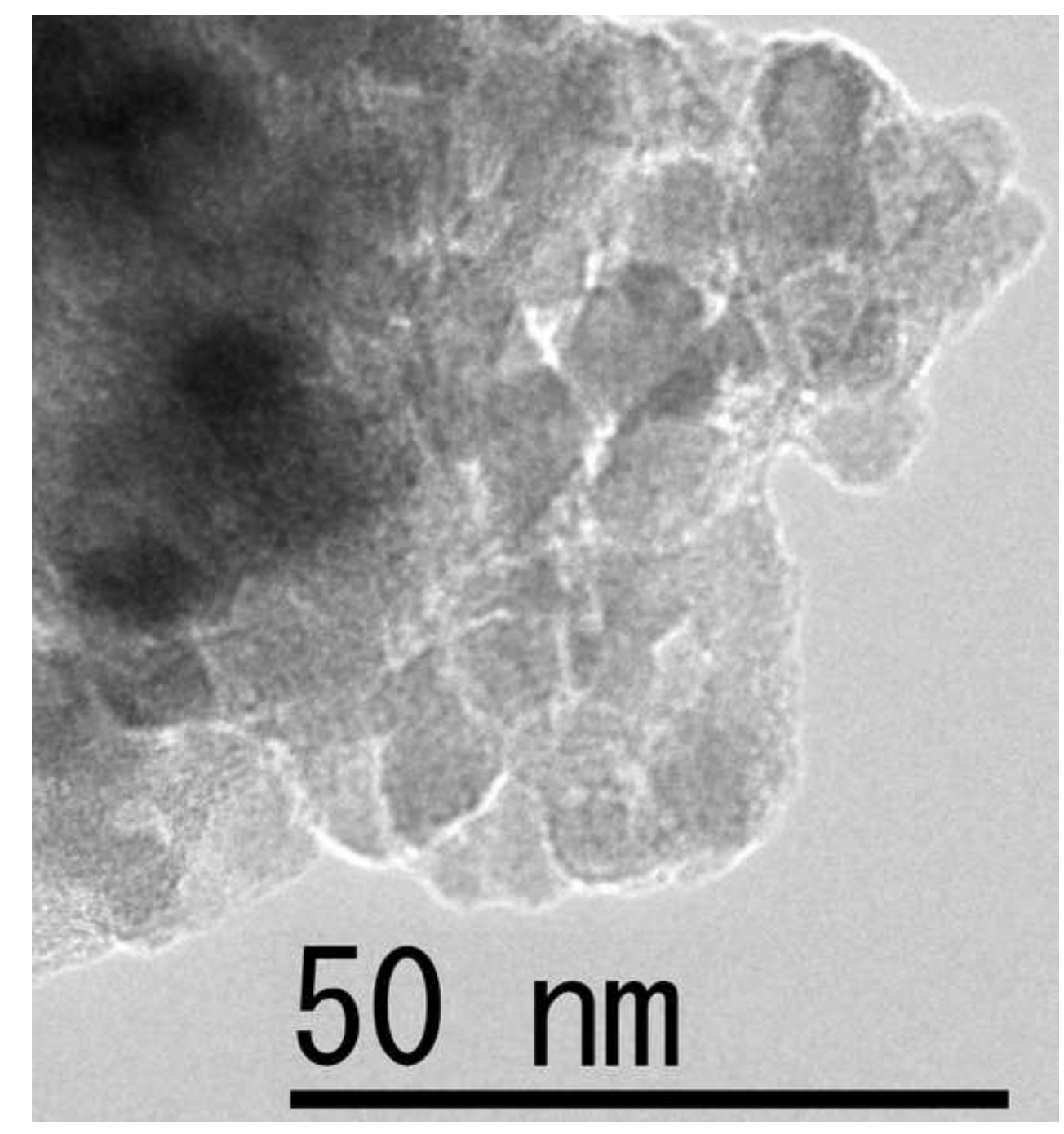

Figure 2 
Figure 3
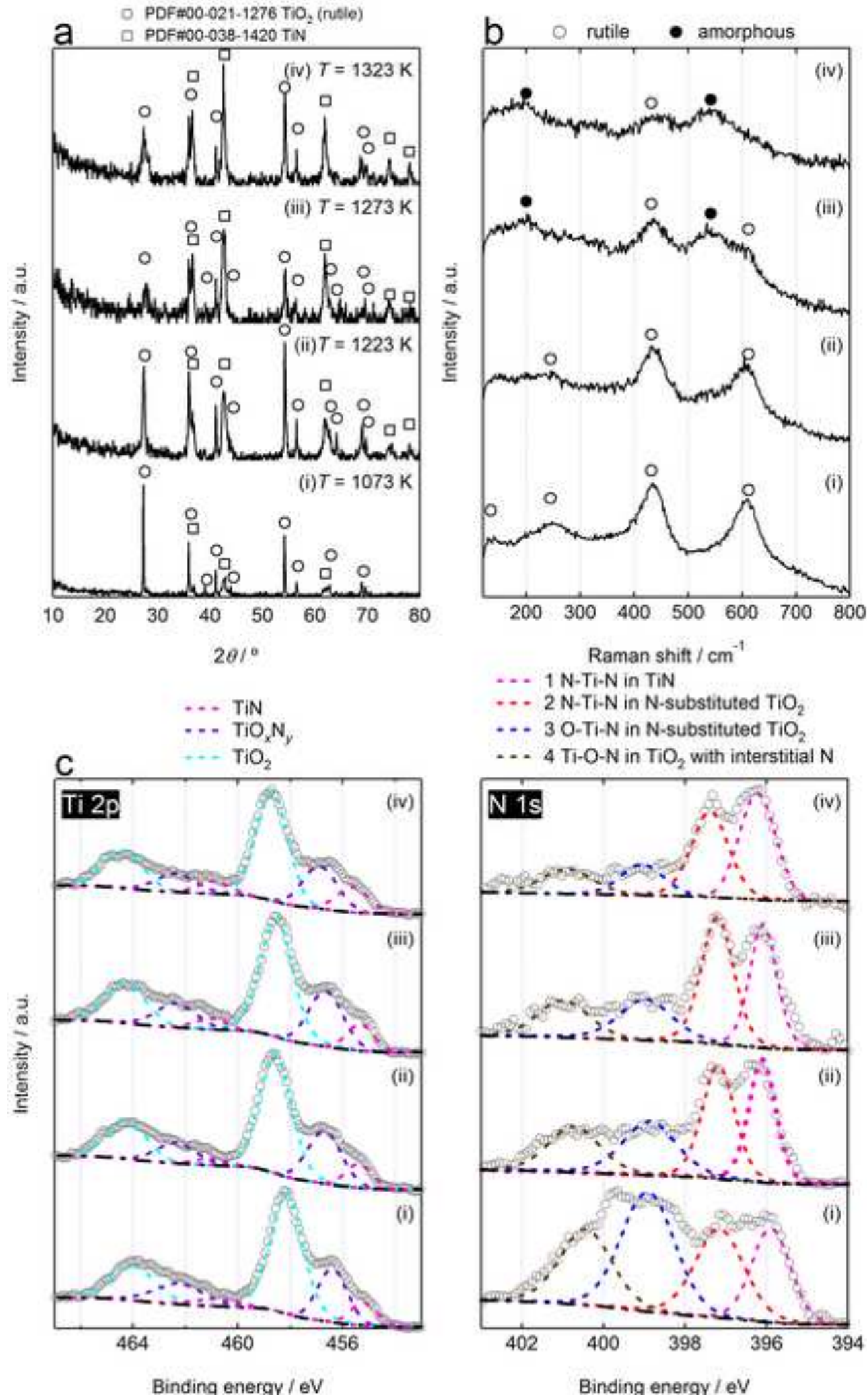

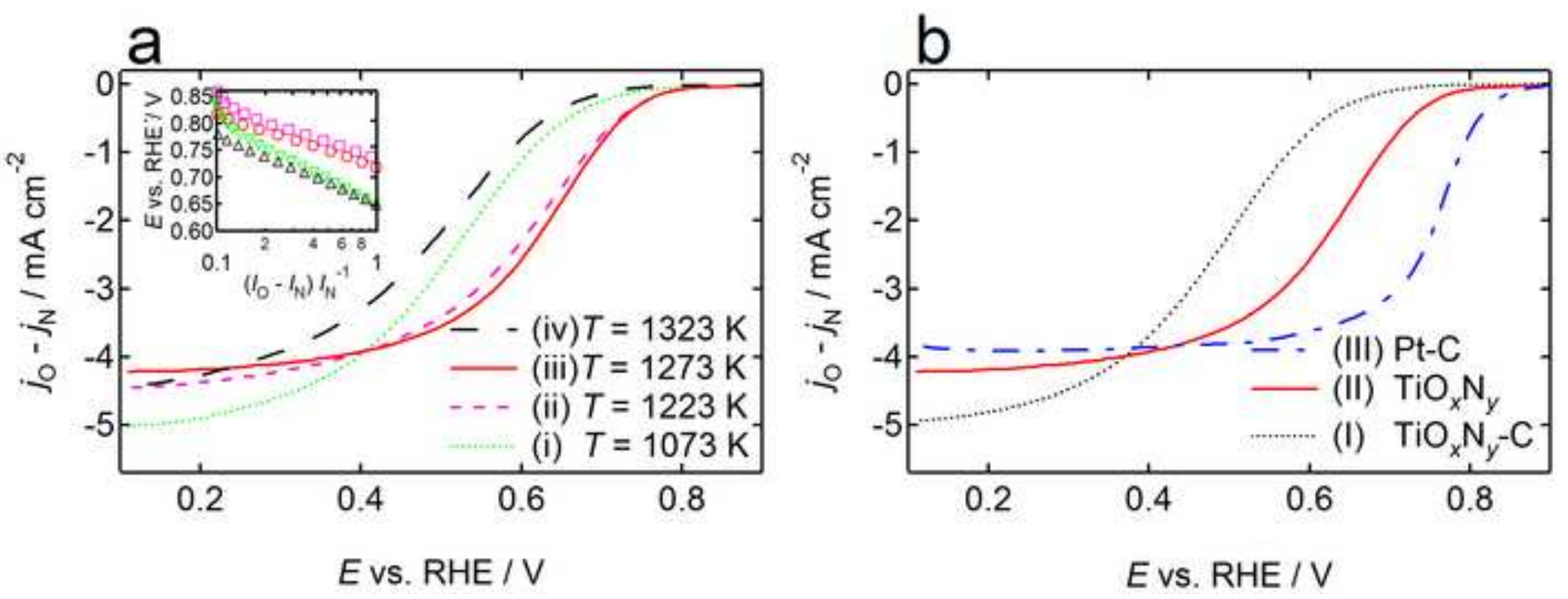


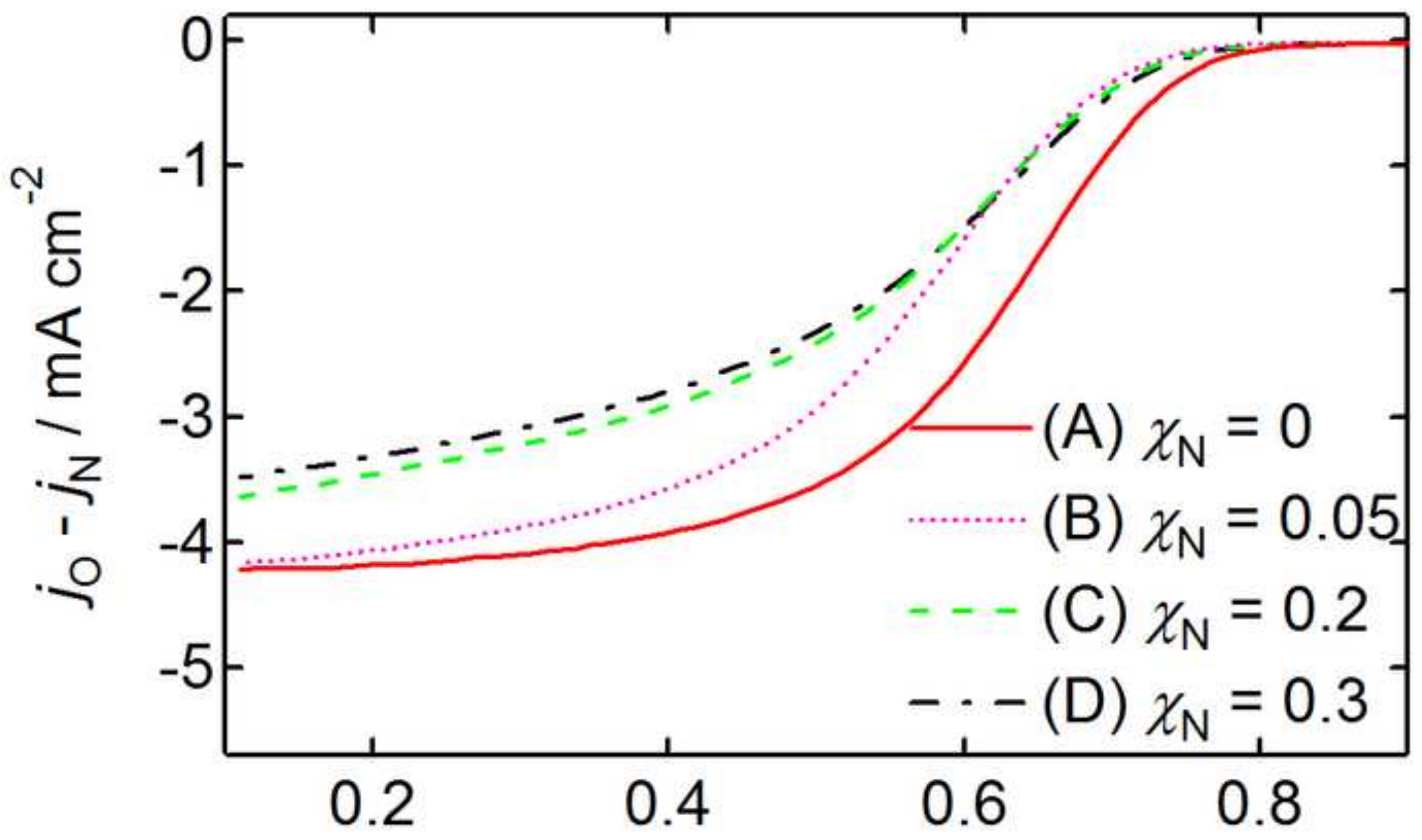

E vs. RHE / V 

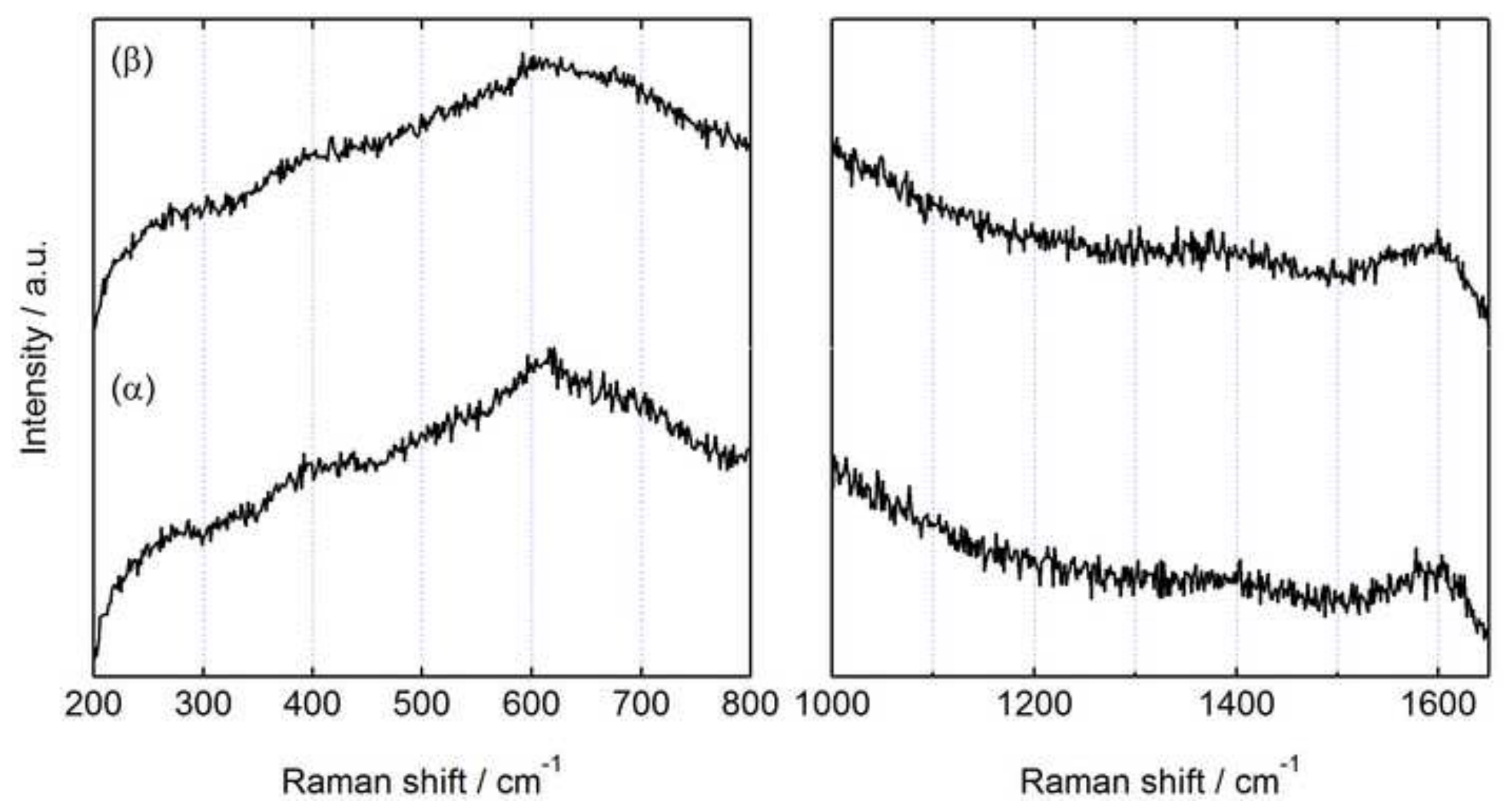

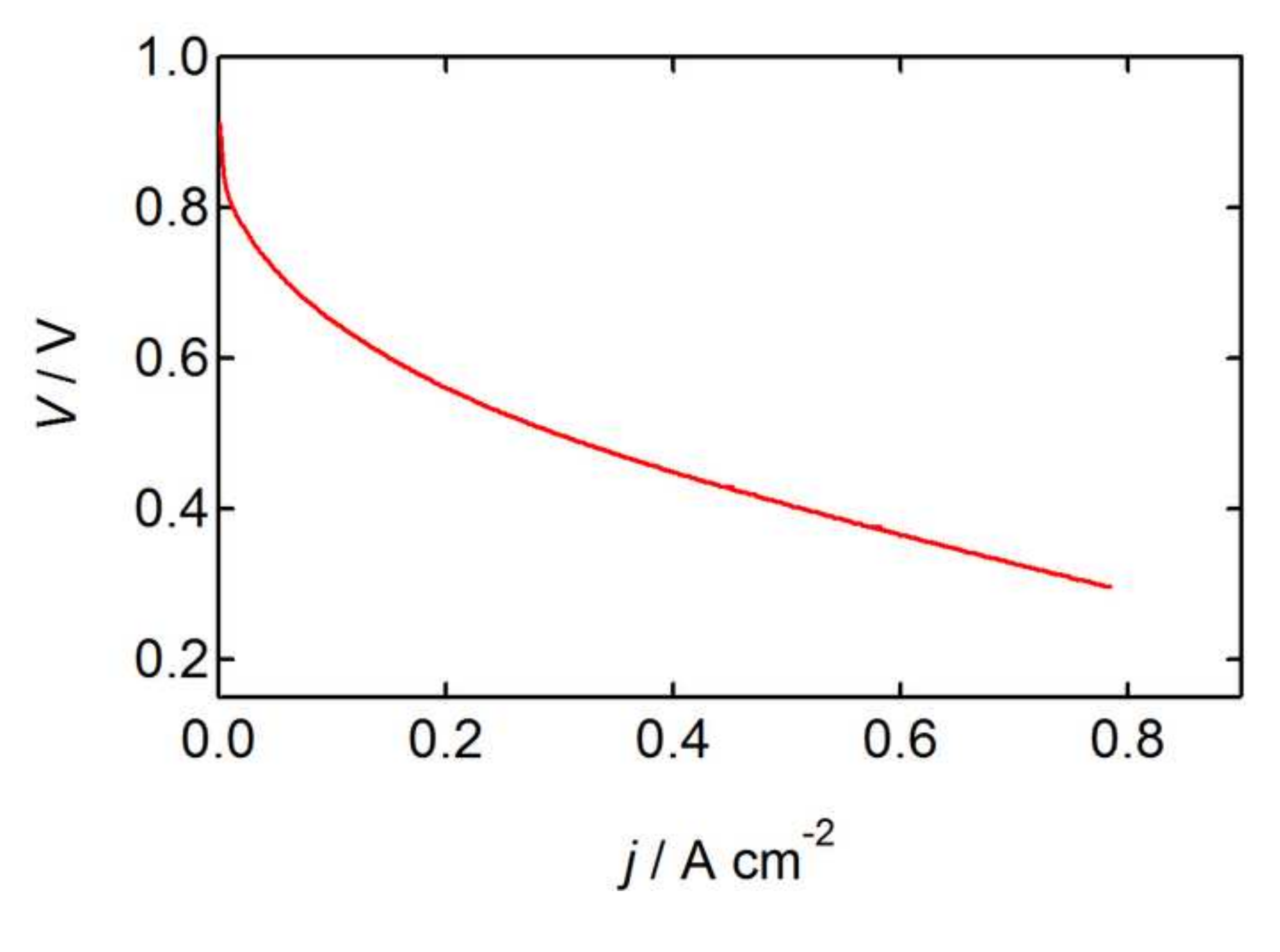

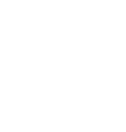

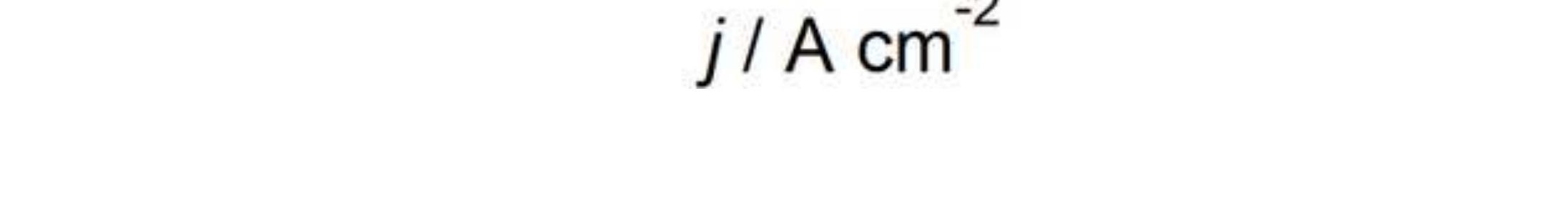




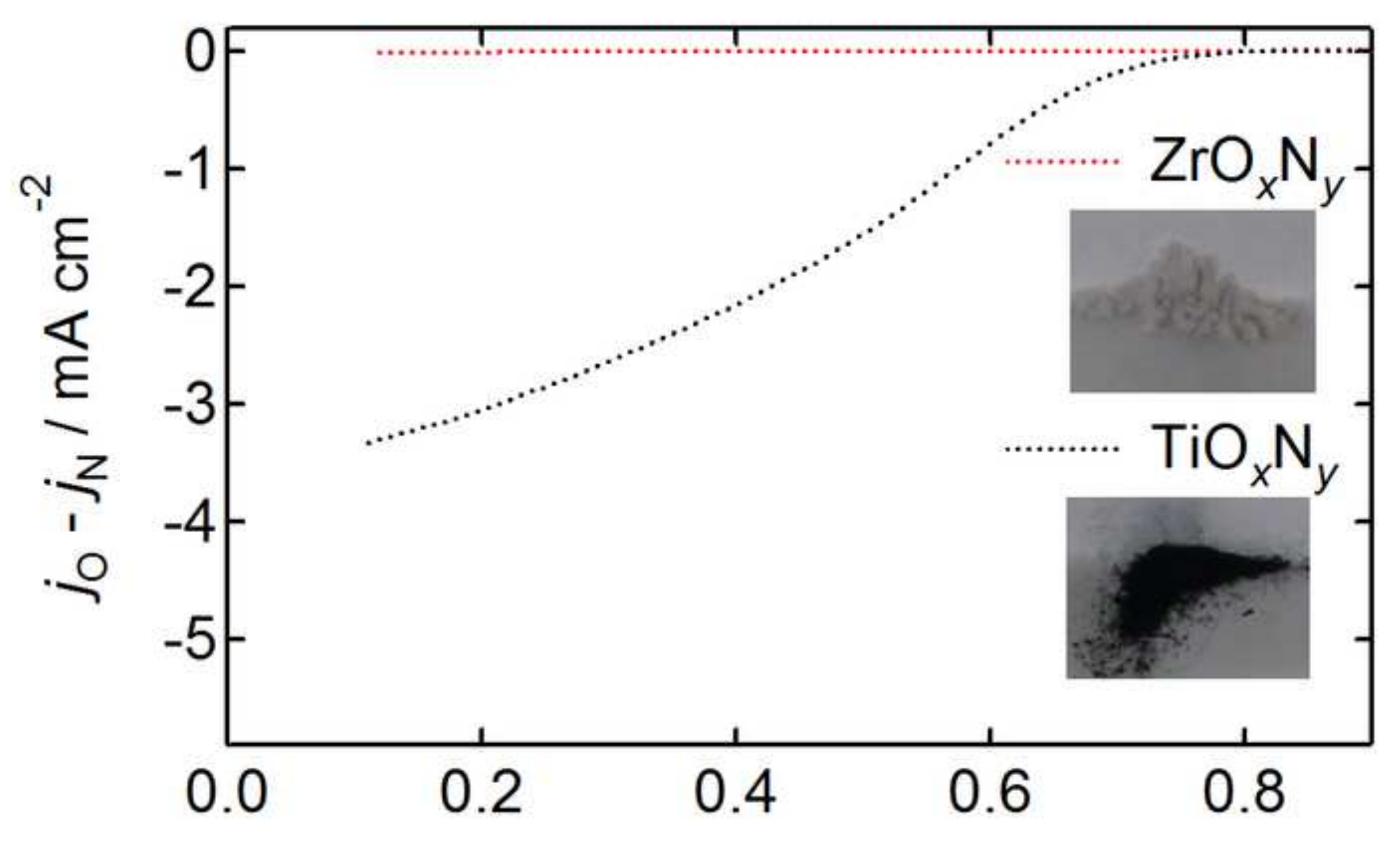

E vs. RHE / V 


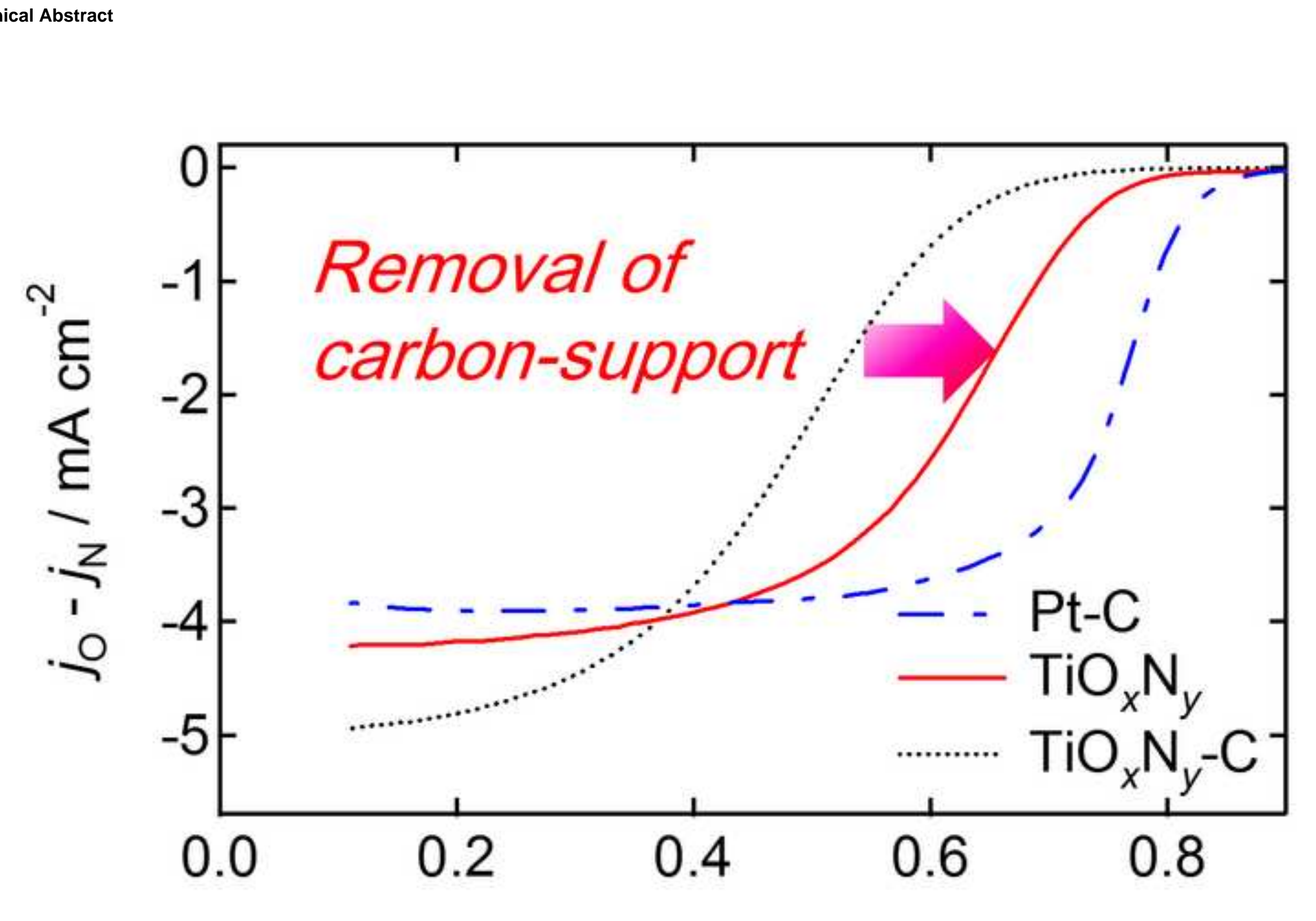

E vs. RHE / V

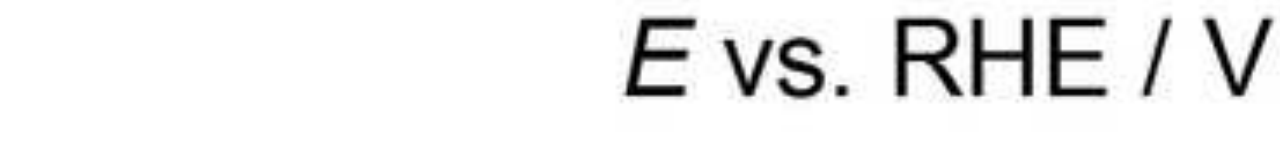

.

(

